\title{
Evaluation of produced water toxicity from an oil maritime terminal through Skeletonema costatum toxicity tests
}

\author{
Aidar, Elizabeth; Sigaud-Kutner, Teresa C. S.; Bicego, Márcia C.; Schinke, Katya P.; Gianesella, \\ Sonia M. F. \& Braga, Elisabete S.
}

Instituto Oceanográfico da Universidade de São Paulo

(Caixa Postal 66149, 05315-970, São Paulo, SP, Brazil)

- Abstract: The liquid effluent from an oil maritime terminal, with produced water as the main component, had its toxicity evaluated through toxicity tests with the diatom Skeletonema costatum. Two previously treated effluent samples (effluents A and B), were provided by PETROBRAS for the experiments. Both samples presented high salinity (67\%o for effluent A and $62 \%$ for effluent B) and low $\mathrm{pH}$ values (6.2), whereas total sulphide, phenol and nutrient content, dissolved/dispersed petroleum hydrocarbon concentration, BOD and COD values were quite different from each other. During the toxicity experiment, three replicate flasks with samples for each treatment were exposed to a light radiation of $266 \mu \mathrm{E} \mathrm{m}^{-2} \mathrm{~s}^{-1}$ and maintained under a $10 \mathrm{~h} / 14 \mathrm{~h}$ light/dark cycle, at a temperature of $24 \pm$ $2^{\circ} \mathrm{C}$. The EC 50 values could not be accurately estimated for effluent A: $60 \mathrm{~h}$ and $132 \mathrm{~h}$ after starting the experiment they were below $3 \%$ and between 3-6\% effluent concentration, respectively. Synergistic effects between effluent toxicity and salinity on the growth of $S$. costatum were detected. The effluent B showed higher toxicity: the $\mathrm{EC}_{50}$ values were $0.17 \%$ and $0.40 \%$ of effluent concentrations, after $48 \mathrm{~h}$ and $96 \mathrm{~h}$, respectively. These results evidenced the deleterious effects of residual organic compounds contained in the aqueous effluents from the oil terminal under the present pretreatment on $S$. costatum. In the light of the present data, the direct disposal of these effluents into São Sebastião Channel waters might be very hazardous to its indigenous biota.

- Resumo: A toxicidade do efluente líquido do "Dutos e Terminais Centro-Oeste São Paulo" (DTCS) terminal marítimo de petróleo da PETROBRAS, em São Sebastião (SP, Brasil), cujo principal componente é a água de produção, foi avaliada através de testes de toxicidade com a diatomácea Skeletonema costatum. Amostras de dois efluentes (A e B), previamente tratados pela PETROBRAS, foram utilizadas nos experimentos. As duas amostras apresentaram alta salinidade $(A=67 \%$; $B=62 \%)$ e baixo valor de $\mathrm{pH}(6,2)$, enquanto que as suas concentrações de sulfetos, fenóis e hidrocarbonetos de petróleo dissolvidos/dispersos, bem como os seus valores de DBO e DQO, foram bastante distintos. Nos experimentos de toxicidade, os frascos experimentais, em triplicata, para cada tratamento

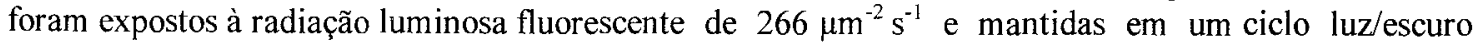
de $10 \mathrm{~h} / 14 \mathrm{~h}$, a uma temperatura de $24 \pm 2{ }^{\circ} \mathrm{C}$. Os valores de $\mathrm{CE}_{50}$ não puderam ser determinados com precisão para o efluente A: após $60 \mathrm{~h}$ e $132 \mathrm{~h}$ do início dos experimentos esses valores estavam abaixo de $3 \%$ e entre $3-6 \%$ da concentração de efluente, respectivamente. Foi observado sinergismo entre a toxicidade e a salinidade do efluente sobre o crescimento de $S$. costatum. O efluente B apresentou uma toxicidade mais elevada: os valores de $\mathrm{CE}_{50}$ foram $0,17 \%$ e $0,40 \%$ da concentração do efluente, após $48 \mathrm{~h}$ e $96 \mathrm{~h}$, respectivamente. Estes resultados evidenciaram claramente os efeitos deletérios dos compostos orgânicos residuais contidos no efluente líquido do DTCS, sobre $S$. costatum. Pode-se concluir que a disposição do efluente nas águas do canal de São Sebastião poderá ser prejudicial à biota local.

- Descriptors: Produced water, Oil terminal, Toxicity tests, Skeletonema costatum.

- Descritores: Água de produção, Terminal de óleo, Testes de toxicidade, Skeletonema costatum.

Contr. no. 831 do Inst. oceanogr. da Usp. 


\section{Introduction}

The "Dutos e Terminais Centro-Oeste São Paulo" (DTCS) - the oil maritime terminal of PETROBRAS, in São Sebastião (SP, Brazil) generates a liquid effluent which is a complex mixture of produced water, ballast water and fresh water used for salinity reduction of crude oil and produced water.

Produced water - an oilfield brine associated with the extracted oil and gas (Daniels \& Means, 1989) - is the main component of the liquid effluent. It contains a large spectrum of dissolved organic and inorganic compounds which differs for each crude oil source (Somerville et al, 1987). These compounds, if discharged into marine waters, are potentially harmful to all organisms. Marine ecosystems receiving treated produced water discharges showed alterations in the normal growth pattern of organisms from the intertidal zone (Somerville $e t$ al., op. cit.) and chromosome aberrations in fish embryos (Daniels \& Means, op. cit.). The most serious biological effects are more likely to occur in coastal waters receiving such discharges (Read \& Blackman, 1980), where physical conditions to disperse the chemical toxicants can be less effective.

The discharge of the aqueous effluent generated by crude oil operations into waters of São Sebastião Channel has been planned by PETROBRAS. Nevertheless, the hazard assessment of such a complex effluent to an ecosystem, based solely on chemical characterization is usually unsatisfactory (Svanberg \& Renberg, 1988). In this context, a program of toxicological tests using a gastropod (Sousa \& Tommasi, 1997), a mysid (Phan et al., 1994) and the diatom Skeletonema costatum (present work) was carried out to estimate the environmental impact of the aqueous effluent discharges into the channel waters.

\section{Materials and methods}

\section{Effluent samples and analyses}

Two effluent samples from DTCS were chemically treated by PETROBRAS, with the purpose of eliminating phenols and sulphides. After treatment they received $20 \%(\mathrm{v} / \mathrm{v})$ of contaminated drainage water from tank areas, in order to simulate the actual liquid effluent composition from the oil company. These samples, obtained in November, 1991 (effluent A) and in January, 1992 (effluent B), were used for toxicity testing. They were stored in white poliethylene flasks and kept at $0^{\circ} \mathrm{C}$, for nearly 12 hours, before starting the assays.
Salinity and $\mathrm{pH}$ were determined with a refractometer (Atago) and a Beckman potentiometer, respectively. Total sulphide and phenol concentrations, biological oxygen demand (BOD) and chemical oxygen demand (COD) (APHA, 1985), dissolved/dispersed petroleum hydrocarbons (Ehrhardt, 1983), as well as phosphate and silicate (Grasshoff, 1976), nitrate and nitrite (Treguer \& Le Corre, 1975) and total ammonia (Strickland \& Parsons, 1968) concentrations were analysed.

\section{Experimental design}

Because of the chemical characteristics of the effluents (high salinity and low $\mathrm{pH}$ values) a special experimental design was carried out for the tests. Convenient volumes of :

a) Seawater ( $\mathrm{S}=34 \%$; $\mathrm{pH}=7.95)$, collected in a nonpolluted area;

b) Effluent;

c) ASP-2 artificial seawater (Provasoli et al., 1957) $(\mathrm{S}=67 \% 0 ; \mathrm{pH}=6.80)$ and

d) Distilled water,

were enriched, separately, with nutrient salts and vitamin concentrations according to Guillard F/8, modified from Guillard (1975), and subsequently filtered through Whatman $\mathrm{GF} / \mathrm{F}(\cong 0.7 \mu \mathrm{m}$ nominal pore size ) glass fiber filters.

The above four "culture media" were used in the experiments described below.

In the Experiments I (effluent A) and IV (effluent B), a hypothetical mixing zone was simulated, i.e. the area where waste water discharges and the receiving seawater mix, as defined by Macek (1985). Volumes of seawater (a) and effluent (b) were mixed in different proportions ranging from zero $($ control $=$ seawater medium) to $100 \%$ effluent concentration (Experiment I) and from zero to 3\% effluent concentration (Experiment IV). As the effluent $B$ volumes used for the dilutions were small they were neither filtered nor enriched with nutrients. Salinity and $\mathrm{pH}$ values for each effluent sample and concentration are shown in Table 1.

In Experiment II, the purpose was to discriminate the effects of toxicants of the effluent from those of osmotic stress on $S$. costatum growth. This experiment was performed only with effluent $A$, due to the high effluent concentrations which were tested. The salinity of the mixtures with different proportions of seawater (a) and effluent A (b), was maintained constant $(34 \%$ ), by previous addition of an appropriate volume of distilled water (d) to the former. The assayed effluent concentrations were the same as those in Experiment I. 
Experiment III was planned to assess the adaptive potential of $S$. costatum to osmotic shocks (as it occurred in Experiment I) since inocula were not pre-conditioned to high salinities resulting from the mixture of seawater with high salinity aqueous effluent. Artificial seawater (c) and seawater (a) media were mixed at the proportions selected for Experiments I and II (Table 1). Salinity and pH values varied for the different proportions of the components of the mixtures. Variations in $\mathrm{pH}$ values were disregarded as $S$. costatum tolerates a wide range of $\mathrm{pH}$ (Aidar-Aragão, 1980).

Experiments with effluent A (Experiments I to III) were carried out in triplicates and those with effluent B (Experiment IV) were performed using quadruplicates for each assayed concentration.

\section{Toxicity tests}

The diatom Skeletonema costatum (Strain $\mathrm{Sk}-\mathrm{Ub}_{2}$ ) was selected for the tests since it is an ecologically important component of the phytoplankton in the southeastern coastal waters. It was isolated from non-polluted coastal waters (Ubatuba, SP) and maintained in cultures at the Marine Microalgae Laboratory of the Instituto Oceanográfico - USP. The clonal isolate was maintained in batch culture with Guillard F/2 culture medium (Guillard, 1975) at 30\% salinity. For preparation of inocula, a $S$. costatum culture in exponential growth phase was washed by centrifugation in a sterilized nutrient poor seawater. Before starting the experiments, the washed cells were kept in this nutrient poor seawater for either two (effluent B) or three (effluent A) days, for depletion of nutrient internal pool. Cells were inoculated into experimental flasks containing the range of effluent concentrations to yield initial densities of about $4 \times 10^{3}$ cells $\mathrm{ml}^{-1}$, in a final experimental volume of $75 \mathrm{ml}$.

The cultures were exposed to light radiation of $266 \mu \mathrm{E} \mathrm{cm}^{-2} \cdot \mathrm{s}^{-1}$, measured by a LICOR Quantameter, and provided by OSRAM "daylight" fluorescent lamps, under a $10 \mathrm{~h} / 14 \mathrm{~h}$ light/dark cycle. Temperature was maintained at $24 \pm 2^{\circ} \mathrm{C}$.

Cultures were shaken once a day, before sampling. Cells growth was monitored by daily "in vivo" fluorescence measurements, using a Turner fluorometer, model 111. The fluorescence data were $\log$ transformed and in order to have positive results, an unit was added $(\log F+1)$. Lag time for growth was estimated in hours; maximum growth rates, in units of divisions per day, were calculated using the least squares method of linear regression on the logarithmically transformed data in the exponential growth phase, according to Guillard (1973). Cell countings were performed by using hemacytometers, after either 60 and $132 \mathrm{~h}$ (effluent A) or 48 and $96 \mathrm{~h}$ (effluent B).

NOEC was estimated by Dunnet test (Zar, 1984) and EC50 by the method proposed by Hamilton et al. (1977), with $95 \%$ confidence limits. Tukey tests (Zar, op. cit.) were used to test parametrically the existence of intergroup differences among growth rate data.

\section{Results}

Salinity and $\mathrm{pH}$ values for all the experiments are shown in Table 1. A large salinity variation was observed only in Experiments I and III,

Table 1. Initial salinity and $\mathrm{pH}$ values for different concentrations (\%) of effluents A (Exp. I, II) and B (Exp. IV) or artificial seawater (Exp. III) diluted with seawater ( $i=$ impossible to reduce to the level of $34 \%$ salinity).

\begin{tabular}{|c|c|c|c|c|c|c|c|c|c|c|c|c|}
\hline \multirow{2}{*}{\multicolumn{2}{|c|}{\begin{tabular}{|l|} 
EXPERIMENT \\
\end{tabular}}} & \multicolumn{11}{|c|}{$\begin{array}{l}\text { CONCENTRATION } \\
(\%)\end{array}$} \\
\hline & & \multirow{2}{*}{ 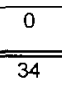 } & \multirow{2}{*}{3} & \multirow{2}{*}{$\frac{6}{36}$} & \multirow{2}{*}{10} & \multirow{2}{*}{$\begin{array}{l}15 \\
39\end{array}$} & \multirow{2}{*}{$\frac{20}{41}$} & \multirow{2}{*}{30} & \multirow{2}{*}{$\frac{50}{251}$} & \multirow{2}{*}{$\stackrel{65}{ }$} & \multirow{2}{*}{$\begin{array}{l}80 \\
61\end{array}$} & \multirow{2}{*}{$\begin{array}{r}100 \\
67\end{array}$} \\
\hline $\bar{I}$ & S\%O & & & & & & & & & & & \\
\hline & $\mathrm{pH}$ & 7.95 & 7.90 & 7.90 & 7.80 & 7.75 & 7.70 & 7.60 & 7.50 & 7.45 & 7.30 & 7.30 \\
\hline \multirow[t]{2}{*}{ II } & S\%o & 34 & 34 & 34 & 34 & 34 & 34 & 34 & 34 & i & i & i \\
\hline & $\mathrm{pH}$ & 7.95 & 7.90 & 7.90 & 7.85 & 7.80 & 7.70 & 7.60 & 7.40 & i & i & $i$ \\
\hline \multirow[t]{2}{*}{ III } & S\%O & 34 & 35 & - & 38 & - & 41 & - & 51 & 56 & 61 & 67 \\
\hline & $\mathrm{pH}$ & 795 & 8.10 & - & 8.00 & - & 790 & - & 7.60 & 7.40 & 7.20 & 6.80 \\
\hline
\end{tabular}

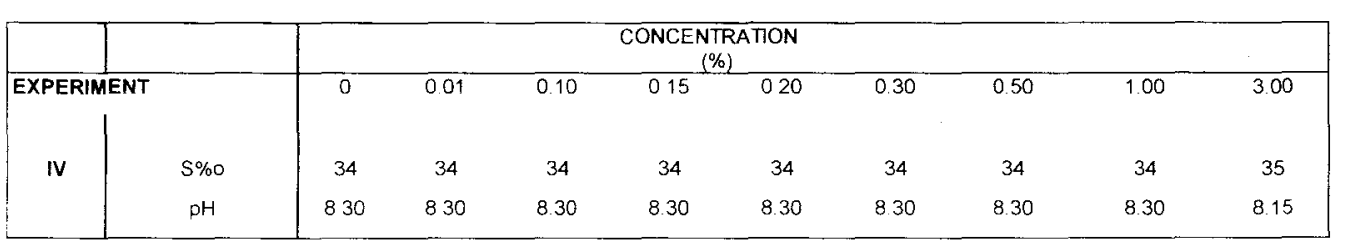


because of either the high salinity of effluent $A$ or of the artificial seawater; $\mathrm{pH}$ values decreased with effluent concentration increase. In contrast, effluent $B$ did not cause significant changes, neither in salinity, nor in $\mathrm{pH}$, due to the small volume added in the experimental flasks. The nutrient concentrations, for seawater and effluent samples before the enrichment, are presented in Table 2. Very high concentrations of ammonium and orthosilicic acid were found in effluent $A$ and $B$, respectively. Nutrient contents varied for each effluent sample as well as for each seawater used in the tests.

Table 2. Nutrient concentration ( $\mu \mathrm{mol} \mathrm{l^{-1 }}$ ) in effluents and seawater ( $\mathrm{ud}=$ undetectable).

\begin{tabular}{|lcccccc|}
\hline & \multicolumn{2}{c}{ EXPERIMENTS } & $\mathrm{I}-\mathrm{II}-\mathrm{HI}$ & & \multicolumn{2}{c|}{ EXPERIMENT IV } \\
\cline { 2 - 3 } \cline { 5 - 6 } NUTRIENTS & Seawater & Effluent A & & Seawater & Effluent B \\
$\mathrm{P}-\mathrm{PO}_{4}$ & 0.24 & 0.58 & & 0.77 & ud \\
$\mathrm{Si}-\mathrm{Si}(\mathrm{OH})_{4}$ & 87.60 & 3.20 & & 8.09 & 313.90 \\
$\mathrm{~N}-\mathrm{NH}_{4}$ & 4.20 & 122.10 & & 0.78 & 2.00 \\
$\mathrm{~N}-\mathrm{NO}_{2}$ & 0.92 & 0.37 & & 0.13 & ud \\
$\mathrm{N}-\mathrm{NO}_{3}$ & 4.60 & 1.12 & 5.72 & 1.20 \\
\hline
\end{tabular}

BOD and COD values, sulphides, phenols, and dissolved/dispersed petroleum hydrocarbon concentrations in the effluents are shown in Table 3. All data were higher for effluent $B$, as compared with those of effluent A.

Concerning toxicity tests with $S$. costatum, at least a $12 \mathrm{~h}$ lag time occurred before growth was observed for Experiments I, II, and III, for all experimental conditions, including the controls (Table 4; Figs 1-3). In the experiment IV, no lag time was detected up to $0.15 \%$ effluent concentration (Table 4; Fig. 4). These differences could be attributed to the lenght of the nutrient depletion periods, to which the cells were submitted before starting the experiments.

Experiment I - A gradual decrease of salinity and increase of $\mathrm{pH}$ occurred with the dilution of the effluent, simulating the increase of distance from the effluent outfall (Table 1). There was a significant increase (about $72 \%$ ) of $S$. costatum cell number at $3 \%$ effluent concentration $\left(1.46 \times 10^{5}\right.$ cells $\left.\mathrm{ml}^{-1}\right)$, compared to the control $\left(0.85 \times 10^{5}\right.$ cells $\left.\mathrm{ml}^{-1}\right)$,

Table 3. Chemical composition, BOD and COD values of effluents.

\begin{tabular}{|c|c|c|c|c|c|}
\hline EFFLUENT & $\begin{array}{c}\text { BOD } \\
\left(\mathrm{mg} \mathrm{l}^{-1} \mathrm{O}_{2}\right)\end{array}$ & $\begin{array}{c}\text { COD } \\
\left(\mathrm{mg} \mathrm{l}^{-1} \mathrm{O}_{2}\right)\end{array}$ & $\begin{array}{c}\text { SULPHIDES } \\
\left(\mathrm{mg} \mathrm{l}^{-1}\right)\end{array}$ & $\begin{array}{c}\text { PHENOLS } \\
\left(\mathrm{mg} \mathrm{l}^{-1}\right)\end{array}$ & $\begin{array}{c}\text { TOTAL PETROLEUM } \\
\text { HYDROCARBON } \\
\left(\mathrm{mg} \mathrm{l}^{-1}\right)\end{array}$ \\
\hline $\mathrm{A}$ & 62 & 84 & - & 0.36 & 5.53 \\
\hline $\mathrm{B}$ & 423 & 889 & 11 & 1.32 & 9.40 \\
\hline
\end{tabular}

Table 4. Maximum growth rates in $\operatorname{div} \operatorname{day}^{-1}( \pm \mathrm{SD})$ and lag time (hours) for growth under different concentrations $(\%)$ of effluents A (Exp. I, II) and B (Exp. IV) or artificial seawater (Exp. III) diluted with seawater. Different superscript letters (i.e., $a b \neq c e ; a c \neq e$ ) or same superscript letters (i.e., $a e=c e ; a a=a b)$ for each effluent separately, indicate that values are or are not significantly different $(\alpha \leq 0.10)$.

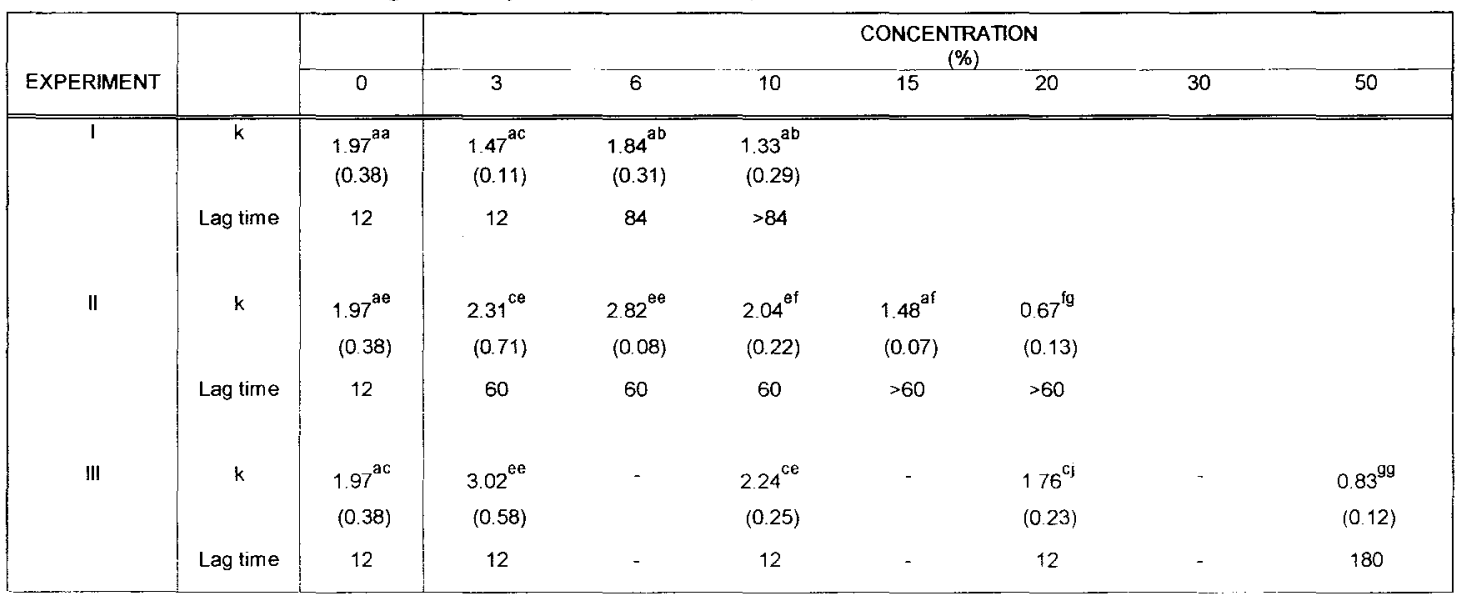

\begin{tabular}{|c|c|c|c|c|c|c|c|c|c|c|}
\hline \multirow{2}{*}{ EXPERIMENT } & & \multirow[b]{2}{*}{0} & \multirow[b]{2}{*}{0.01} & & \multicolumn{2}{|c|}{$\begin{array}{c}\text { CONCENTRATION } \\
(\%)\end{array}$} & \multirow[b]{2}{*}{0.30} & \multirow[b]{2}{*}{0.50} & \multirow[b]{2}{*}{1.00} & \multirow[b]{2}{*}{3.00} \\
\hline & & & & 0.10 & 0.15 & 0.20 & & & & \\
\hline \multirow[t]{3}{*}{ IV } & k & $1.52^{\mathrm{aa}}$ & $1.88^{b c}$ & $1.67^{\mathrm{ab}}$ & $1.60^{a b}$ & $1.80^{a b}$ & $1.87^{b C}$ & $2.01^{c d}$ & $2.28^{d d}$ & $2.24^{d d}$ \\
\hline & & $(0.13)$ & $(0.19)$ & $(0.05)$ & $(0.05)$ & $(0.20)$ & $(0.08)$ & $(005)$ & $(011)$ & $(0.08)$ \\
\hline & Lag time & 0 & 0 & 0 & 0 & 24 & 24 & 24 & 24 & 72 \\
\hline
\end{tabular}


$132 \mathrm{~h}$ after starting the experiment (Fig. 1). At 6 and $10 \%$ effluent concentrations (Table 4 ), a remarkable increase of the lag time was observed, with a tendency of decrease of the maximum growth rate. At $15 \%$ effluent concentration, S. costatum did not grow at all.

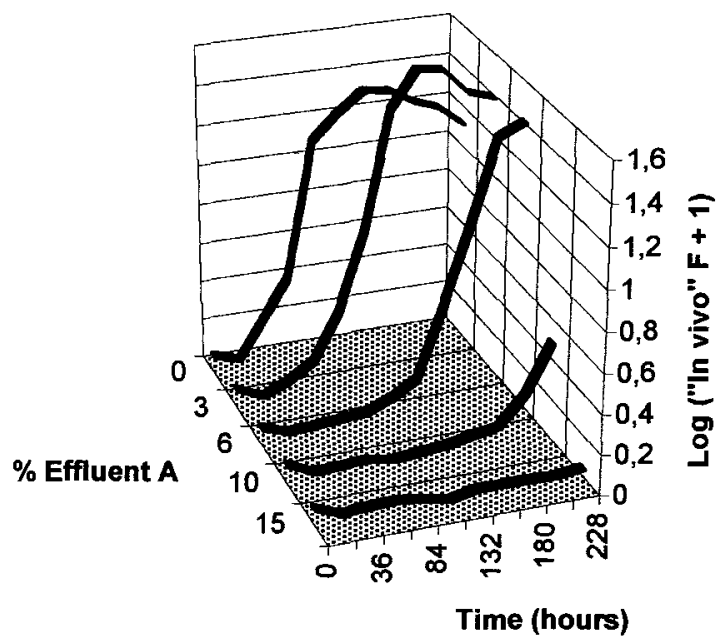

Fig. 1. Growth curves of $S$. costatum under different concentrations of effluent A (Experiment I), Growth in log of "in vivo" fluorescence +1 .

Experiment II - Salinity was kept constant in this assay and $\mathrm{pH}$ ranged from 7.95 in the control to 7.40 , at $50 \%$ effluent concentration (Table 1). Lag time increased with effluent concentration (Table 4). At 3 and $6 \%$, although no significant differences were observed on the maximum growth rate data, there is a tendency of a stimulant effect in relation to the control, as well as in the cell number (not shown) which increased $75 \%$ and $67 \%$ respectively, $132 \mathrm{~h}$ after starting the experiment. Towards $20 \%$ effluent concentration the maximum growth rate decreased sharply. Growth curves relative to these conditions (Fig. 2) were very close to that obtained at 3\% effluent concentration in Experiment I (Fig. 1). At a $10 \%$ effluent concentration, $S$. costatum grew better than at the same concentration in Experiment I. Cells divided even in up to $20 \%$ effluent concentration, albeit under a low growth rate and after a lag phase longer than $60 \mathrm{~h}$.

Experiment III - Salinity and $\mathrm{pH}$ changed with different concentrations of artificial seawater (Table 1). Lag time was $12 \mathrm{~h}$ long for all treatments including the control while the division rate decreased significantly in higher salinities (Table 4). Cells grew well up to $41 \%$ ( $20 \%$ artificial seawater concentration). However, at $51 \%$ (50\% artificial seawater concentration) growth was incipient and at
$56 \%$ (65\% artificial seawater concentration) the species did not grow at all (Table 4; Fig. 3).

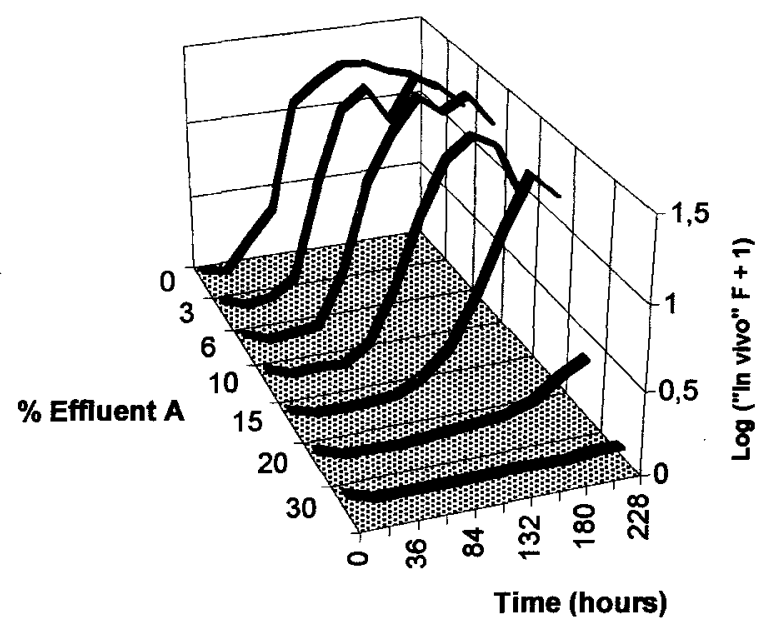

Fig. 2. Growth curves of $S$. costatum under different concentrations of effluent $\mathrm{A}$, at $34 \%$ salinity (Experiment II). Growth in log of "in vivo" fluorescence +1 .

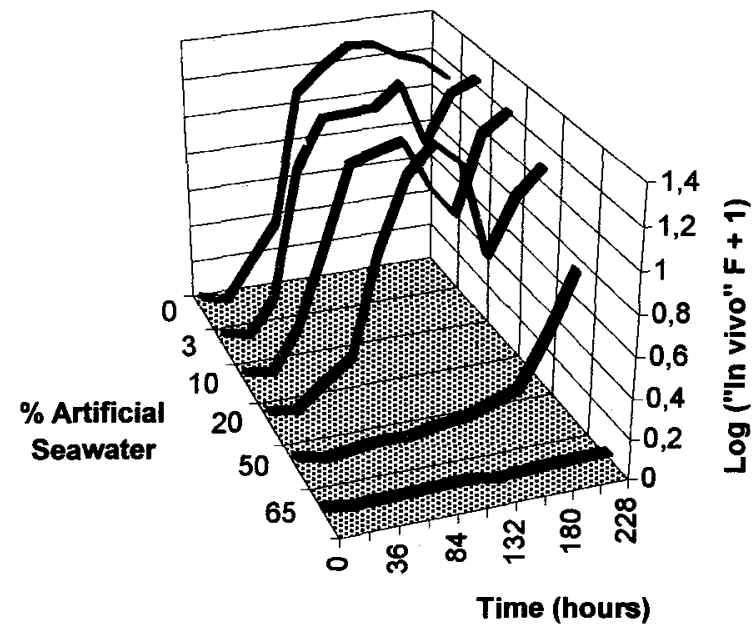

Fig. 3. Growth curves of $S$. costatum under different concentrations of artificial seawater $(S=67 \%$ ) and seawater (Experiment III). Growth in log of "in vivo" fluorescence +1 .

Synergistic effects on cell growth between salinity and effluent toxicants can be observed through the maximum growth rate data (Table 4): at all concentrations the values were significantly lower in Experiment I than in Experiments II and III. So, cell number for Experiments I and II differred after 60 and $132 \mathrm{~h}$ ( $\mathrm{p}<0.004$ and $\mathrm{p}<0.001$, respectively), with probable alterations on $\mathrm{EC}_{50}$ values for the effluent. It was not possible to accurately estimate, $\mathrm{EC}_{50}$ values for effluent $\mathrm{A}$. However considering cell 
counts after 60 and $132 \mathrm{~h}, \mathrm{EC}_{50}$ values seem to be below $3 \%$ and between 3 and $6 \%$ effluent concentration, respectively (Experiment I). Nevertheless, if salinity is constant (Experiment II), the $\mathrm{EC}_{50}$ was below $3 \%$ effluent concentration, after $60 \mathrm{~h}$ and between $10-15 \%, 132 \mathrm{~h}$ after beginning the experiment.

Experiment IV - Effluent B differred from effluent A by its greyish color and very strong smell. As $3 \%$ was the highest effluent concentration tested, salinity and $\mathrm{pH}$ changes were slight (Table 1). Lag time increased with effluent concentration (Table 4). Nevertheless, the maximum growth rate was significantly stimulated, so that at $3 \%$ effluent concentration, the remaining viable cells recovered normal growth after a $72 \mathrm{~h}$ lag time, yielding a delayed maximum "in vivo" fluorescence as high as that in the control (Fig. 4).

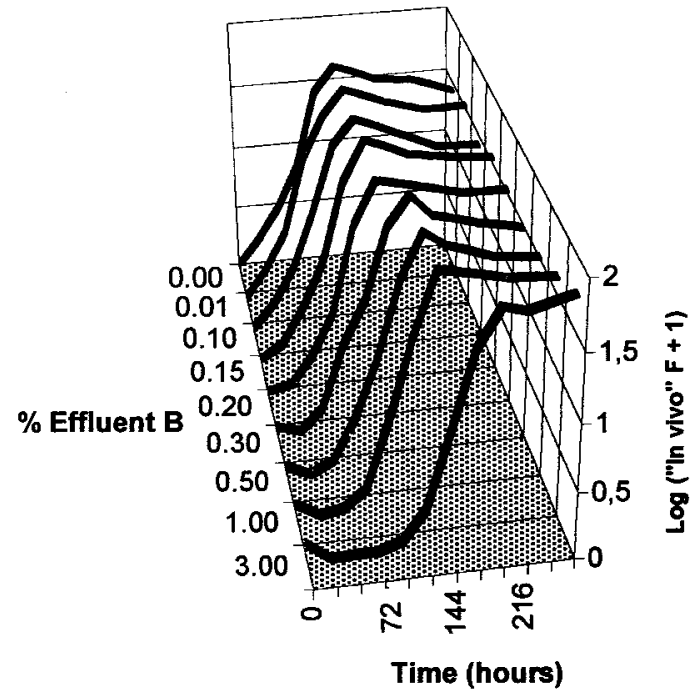

Fig. 4. Growth of $S$. costatum under different concentrations of effluent B (Experiment IV). Growth in log of "in vivo" fluorescence +1 .

EC 50 values after $48 \mathrm{~h}$ and $96 \mathrm{~h}$ were $0.17 \%$ and $0.40 \%$ effluent concentrations, respectively; NOEC values were $0.10-0.15 \%$ and $0.15-0.20 \%$ effluent concentrations, after $48 \mathrm{~h}$ and $96 \mathrm{~h}$ exposure, respectively.

\section{Discussion}

Liquid effluents (mainly produced water) generated by crude oil operations contain a large spectrum of inorganic/organic dissolved compounds as well as insoluble material such as high-molecularweight oil fractions and suspended solids. In addition, its composition varies depending on the crude oil source (Somerville et al, 1987) and even on the well age (E \& P Forum, 1994).
One special feature of the produced water is its high salinity. Due to that, synergistic effects of salinity and dissolved toxicants on the phytoplankton growth can be expected. The present results of the toxicity tests with $S$. costatum (Experiment III) showed that if the cells are adapted to $30 \%$, they may overcome an osmotic shock at salinities up to $51 \%$, in the absence of any additional source of physiological stress. On the other hand, if salinity is maintained constant (Experiment II), the cells can grow up to $20 \%$ of the effluent concentration. However, under an actual field condition where salinity and dissolved toxicants are acting synergistically on the living cells (Experiment I), the highest salinity supporting growth decreases to $38 \%$, at an effluent concentration as low as $10 \%$. The same picture can be seen through the maximum growth rate data in the experiments I, II and III, at low concentrations (3-6\%) of effluent or salinity increase: separately they act as "growth stimulants" and together they act as "growth inhibitors".

As was confirmed by our experiments, different liquid effluents may have different toxic potentials. S. costatum growth was seriously affected by only $3-6 \%$ effluent $A$ concentrations, whereas these values fell to concentrations as low as 0.17 $0.40 \%$ for effluent B. These values indicate a toxicity of the tested effluents 10 to 1000 times higher than that found by Brendehaugh et al. (as cited in E \& P Forum, 1994) and Strømgren et al. (1995) using the same test species. Our results were corroborated by Phan et al. (1994) and Sousa \& Tommasi (1997), using mysids and gastropods, respectively, as test organisms: toxicity of effluent $B$ was ten times higher than of effluent $A$.

Low concentrations of liquid effluent can stimulate phytoplankton growth, as can be observed in Figures 1, 2 and 4 . Even at effluent concentrations above the $\mathrm{EC}_{50}$ value, after an initial inhibition of $S$. costatum growth for up to $72 \mathrm{~h}$, cell division was stimulated and the maximum yield surpassed that of controls. As pointed out by Prouse et al. (1976), at concentrations of dissolved petroleum hydrocarbons lower than $0.1 \mathrm{mg} \mathrm{l}^{-1}$, stimulation of growth of Dunaliella tertiolecta occurred while Skeletonema costatum showed no apparent difference in growth responses between 0.35 and $5.0 \mathrm{mg} \mathrm{l}^{-1}$. Indeed, besides the dissolved organic components, high total ammonia concentrations might be important as : an eutrophication agent since nitrogen is the main limiting nutrient in southeastern Brazilian coastal waters (Teixeira et al., 1986).

Nevertheless, interspecific differences in responses of phytoplanktonic species to qualitatively 
and quantitatively different dissolved petroleum hydrocarbons seem to be responsible for changes in the community structure, due to selective inhibition/stimulation of certain species (Shailaja, 1988). It can be surmised that the effect of dissolved petroleum hydrocarbons on the phytoplankton community varies depending on the quality, rather than on the quantity of such dissolved compounds (Shailaja, op.cit.).

Concerning the concentrations of the overall dissolved organic material, high BOD and COD suggest that the effluent could lead to oxygen depletion in the mixing zones (Phan et al., 1994).

Unfortunately, no phytoplankton monitoring has been carried out in areas under influence of produced water discharges from crude oil operation all over the world. Changes in optical properties of seawater column are likely to occur since the effluents show high turbidity. In this context, the local euphotic zone might be seriously reduced and thus, affecting phytoplankton primary production. In the North Sea, it was observed that normal growth pattern of benthic organisms in the intertidal zone was influenced up to a distance of $10-20 \mathrm{~m}$ from the discharge point (Somerville et al., 1987).

The wind driven currents in the São Sebastião Channel, defined by Castro Filho (1990) as highly variable in space and time, must be considered for the effluent disposal. In the mixing zone, under unsuitable conditions of water transport and continuous flow of such high salinity liquid effluent, salinity would be higher than in adjacent areas. Our data show that effluent toxicity for phytoplankton species may be enhanced if a concomitant salinity increase occurs indicating a synergistic action between salinity and effluent toxicity.

The present data suggest that the DTCS liquid effluent discharge into a semi-enclosed area may cause short and long-term ecological hazards to phytoplankton natural assemblages. Actually, Gianesella et al. (1999) have found morphological abnormalities in diatoms of natural assemblages from the channel indicating that a source of stress is already acting in this environment. Therefore, an improvement of the effluent treatment and a continuous monitoring of both lethal and chronical effects of its operational discharges is crucial to prevent larger deleterious effects on this marine ecosystem.

\section{Acknowledgements}

We thank "Fundação de Amparo à Pesquisa do Estado de São Paulo" (FAPESP), "Conselho
Nacional de Desenvolvimento Científico e Tecnológico" (CNPq) for financial support for the Laboratory of Marine Microalgal Cultures IOUSP, "Fundação de Estudos e Pesquisas Aquáticas" (FUNDESPA) and PETROBRÁS, for providing funds for this research and permission for publishing the results. We also thank to the colleagues Phan Van Ngan, Vicente Gomes, Murilo Damato and an anonymous reviewer for the critical reading of the manuscript, to Pablo Augusto Ferrari for the statistical analysis of data and to Ione Irulegui for the English revision.

\section{References}

Aidar-Aragão, E. 1980. Alguns aspectos da autoecologia de Skeletonema costatum (Greville) Cleve, de Cananéia $\left(25^{\circ} \mathrm{S}-48^{\circ} \mathrm{W}\right)$, com especial referência ao fator salinidade. Tese de doutorado. Universidade de São Paulo, Instituto Oceanográfico. 2v.

APHA. American Public Health Association. 1985. Standard methods for the examination of water and waste water, $16^{\text {th }}$ ed. Washington, APHA. 1268 p.

Castro Filho, B. M. de 1990. Wind driven currents in the Channel of São Sebastião: winter, 1979. Bolm Inst. oceanogr., S Paulo, 38(2):111-132.

Daniels, C. B. \& Means, J. C. 1989. Assessment of the genotoxicity of produced water discharges associated with oil and gas production using a fish embryo and larval test. Mar. environ. Res., 28(1-4):303-307.

E \& P Forum. 1994. North sea produced water: fate and effects in the marine environment. Report 2.62/204. 48p.

Ehrhardt, M. 1983. Determination of petroleum residues dissolved and/or finely dispersed in surface seawater. In: Grasshoff, K., Ehrhardt, M. \& Kremling, K. eds Methods of seawater analysis. $2^{\text {nd }}$ ed. Weinhen, Verlag Chemie. p. 281-290.

Gianesella, S. M. F.; Kutner, M. B. B.; SaldanhaCorrêa, F. M. P. \& Pompeu, M. 1999. Assessment of plankton community and environmental conditions in São Sebastião Channel prior to the construction of a produced water outfall. Rev. bras. oceanogr., 47(1):29-46. 
Grasshoff, K. 1976. Methods of seawater analysis. New York, Verlag Chemie. 317 p.

Guillard, R. R. L. 1973. Division rates. In: Stein, J. R. ed. Handbook of physiological methods: culture methods and growth measurements. Cambridge, Cambridge University Press. p.289311.

Guillard, R. R. L. 1975. Culture of phytoplankton for feeding marine invertebrates. In: Smith, W. L. \& Chanley, M. H. eds Culture of marine invertebrate animals. New York, Plenum Publish. Corporation. p.29-60.

Hamilton, M. A.; Russo, R. C. \& Thurston, R. V. 1977. Trimmed Spearman-Karber method for estimating median lethal concentrations in toxicity bioassays. Environ. Sci. Technol., 11(7): 714-719. Correction: 12 (4):417, 1978.

Macek, K. J. 1985. Effluent evaluation. In: Rand, G. M. \& Petrocelli, S. R., eds. Fundamentals of aquatic toxicology. Methods and applications. New York, Hemisphere Publish. Corporation. p. 636-649.

Phan, V. N.; Gomes,V. \& Passos, M. J. A. C. R. 1994. Avaliação prévia da toxicidade de um efluente simulado derivado de petróleo sobre Promysis atlantica (Crustacea, Mysidacea). Bolm Inst. oceanogr., S Paulo, 42 (1/2):129-141.

Prouse, N. J.; Gordon Jr., D. C. \& Keizer, P. D. 1976. Effects of low concentrations of oil accomodated in sea water on the growth of unialgal marine phytoplankton cultures. J. Fish. Res. Bd Can., 33(4): 810-818.

Provasoli, L.; McLaughlin, J. J. A. \& Droop, M. R. 1957. The development of artificial media for marine algae. Arch. Mikrobiol., 25:392-428.

Read, A. D. \& Blackman, R. A. A. 1980. Oily water discharges from offshore north Sea installations: a perspective. Mar. Pollut. Bull., 11(2): 44-47.

Shailaja, M. S. 1988. The influence of dissolved petroleum hydrocarbon residues on natural phytoplankton biomass. Mar. environ. Res., 25(4): 315-324.
Somerville, H. J.; Bennett, D.; Davenport, J. N.; Holt, M. S.; Lynes, A.; Mahieu, A.; McCourt, B.; Parker, J. G.; Stephenson, R. R.; Watkinson, R. J. \& Wilkinson, T. G. 1987. Environmental effect of water from North Sea oil operations. Mar. Pollut. Bull., 18(10): 549-558.

Sousa, E. C. P. M. \& Tommasi, L. R. 1997. Toxicidade do efluente derivado do terminal marítimo da Petrobrás sobre o gastropoda Costoanachis sertulariarum. Rev. bras. oceanogr., 45(1/2): 95-99.

Strickland, J. D. H. \& Parsons, T. R. 1968. A practical handbook of seawater analysis. Bull. Fish. Res. Bd Can., 167: 1-311.

Strømgren, T.; Sørstrøm, S. E.; Schou, L; Kaarstad, I.; Aunaas, T.; Brakstad, O. G. \& Johansen, $\varnothing$. 1995. Acute toxic effects of produced water in relation to chemical composition and dispersion. Mar. Environ. Res., 40(2):147-169.

Svanberg, O. \& Renberg, L. 1988. Biologicalchemical characterization of effluents for the evaluation of the potential impact on the aquatic environment. In: Angeletti, G. \& Bjørseth, A. eds Organic micropollutants in the aquatic environment. The Netherlands, Kluwer Academic Publishers. p. 244-255.

Teixeira, C.; Kutner, M. B. B; Aidar-Aragão, E. \& Schmidt, G. 1986. Algal assay of limiting nutrients for phytoplankton production and growth at Flamengo Bay (Ubatuba-Brazil). Rev. Brasil. Biol., 46(3):491-506.

Treguer, P. \& Le Corre, P. 1975. Manuel d'analyse des sels nutritifs dans l'eau de mer (utilization de l'autoanalyser II Technicon R). $2^{\text {ème }}$ ed. Université de Bretagne Occidentale. 109 p.

Zar, J. H. 1984. Biostatistical analysis. New York, Englewood Cliffs/Prentice Hall. 718p.

(Manuscript received 17 February 1997; revised 03 November 1999; accepted 17 February 2000) 